\title{
Cross-Border Labor Organizing in the Garment and Automobile Industries: The Phillips Van-Heusen and Ford Cuautitlan Cases
}

\author{
by \\ Ralph Armbruster \\ University of California, Riverside
}

Cite: Armbruster, Ralph. (1998). "Cross-Border Labor Organizing in the Garment and Automobile Industries: The Phillips Van-Heusen and Ford Cuautitlan Cases." Journal of World-Systems Research http://jwsr.ucr.edu/4: 20 - 51.

\begin{abstract}
:
The globalization of the world economy has created new opportu nities for cross-border labor organizing. In this paper I examine two case studies of cross-border labor organizing. One case involves Phillips Van-Heusen (PVH) workers in Guatemala City, and the other Ford automobile workers in Cuautitlan, Mexico. The PVH case illustrates the potential for cross-border labor organizing in the highly mobile garment industry. The PVH workers' union and their cross-border allies adopted a "strategic cross-border organizing model" that included consumer and trade pressure, an active international trade secretariat, and several other strategies, to achieve an amazing victory. However, the Ford Cuautitlan case demonstrates that corporatist state-labor relations and internal union conflicts have limited cross-border organizing in the automobile industry. These two case studies and their different outcomes have many important lessons for academics and activists interested in cross-border labor organizing.

C 1998 Ralph Armbruster.
\end{abstract}

[Page 20]

Journal of World-Systems Research

\section{ACKNOWLEDGEMENTS}

The author gratefully thanks all the Guatemalan, Mexican, and U.S. workers and labor activists for their time and assistance. I especially thank Teresa Casertano and Rodolfo Robles who spoke with me several times and allowed me to understand the complexities of maquila labor organizing and the history of the Guatemalan labor movement. Peace Brigades International, Witness for Peace, and the National Coordinating Office on Refugees and the Displaced of Guatemala (NCOORD) also provided me with helpful information in Guatemala. I also thank Ernesto Barahonce, Mary Beth Kaufinan, Renata Vegalbela, and Elvia Ramirez for translating many of the interviews for this study. I also 
thank Edna Bonacich, Karen Brandow, Henry Frundt, Dan La Botz, and Mary Tong for their generous sharing of information.

\section{Introduction: The Globalization of the World Economy}

The world economy has become increasingly globalized over the last thirty years. Major corporations in the garment, electronics, and automobile industries, like the Gap, Phillips Van-Heusen, General Electric, Zenith, General Motors, and Ford, have moved, expanded, or opened up new production facilities and factories all over the world. In the garment industry, many manufacturers have also established highly dispersed and complex production systems with "contractors" in low-wage cities and nations including Los Angeles, Mexico, Guatemala, El Salvador, China, and in many other locations (Bonacich et al. 1994; Figueroa 1996). Automobile companies have also fragmented production within and between nations through "outsourcing" agreements with auto parts suppliers (Micheli 1994; Womack et al. 1990). In addition, the gradual lowering of tariff barriers, the passage of regional and world trade agreements (e.g. NAFTA and WTO), and the widespread adoption of export-led development policies have also facilitated the globalization of the world economy.

The political, economic, and social consequences of globalization have been widely debated (Brecher and Costello 1994; Greider 1997; Henwood 1996; Meiskins Wood 1997). One of the most critical questions researchers have analyzed is the relationship between labor unions and globalization. Many studies have demonstrated that globalization and the gradual decline of blue-collar, industrial jobs weakened and crippled labor unions in the United States (Bluestone and Harrison 1982; Kamel 1990; Browne and Sims 1993). In addition, numerous studies have examined the growth of new factories and the strict limitations on labor unions in developing nations, like Mexico, Guatemala, China, and South Korea (La Botz 1992; Petersen 1992; Ping 1990; HartLandsburg 1993; Deyo 1989; ICFTU 1996).

[Page 21]

Journal of World-Systems Research

However, very few studies have explored how labor unions are responding internationally to globalization. Early research indicates labor unions are utilizing innovative strategies like corporate campaigns, labor rights_petitions, codes of conduct, consumer activism, and cross-border labor organizing (Armbruster 1995, forthcoming; Alexander and Gilmore 1994; Brecher and Costello 1994; Cook 1997; Frundt 1996; Herod 1995; La Botz 1994; Moody 1995). Labor unions that have used these approaches realize global cooperation and international labor solidarity are necessary given the realities of the contemporary world economy. 
A Brief Historical Overview of International Labor Movements1

Over the last one hundred fifty years workers and labor unions have formed numerous international labor organizations (Lorwin 1953; Windmuller 1954). These organizations produced some positive results, but they largely failed for several reasons. In the preCold War period (1872-1945), 2 ideological divisions, rivalries between national labor federations, and the growing "nationalization" of labor movements undermined the appeal of international labor solidarity (Waterman 1991).

During the Cold War period (1945-1990), the international labor movement was divided into two blocs. The International Confederation of Free Trade Unions (ICFTU) supported national labor federations in the capitalist economies of Western Europe and the United States, while the World Federation of Trade Unions (WFTU) represented communist labor federations in Eastern Europe and the Soviet Union (Waterman 1991). ICFTU and WFTU affiliated labor federations, especially the U.S.-based AFL-CIO (American Federation of Labor-Congress of Industrial Organizations), and the Soviet-based AUCCTU (the All-Union Central Council of Trade Unions), influenced and shaped the political and ideological trajectory of labor unions in developing nations (Sims 1992; Ruble 1981). For instance, the AFL-CIO's Latin American affiliate, the American Institute for Free Labor Development (AIFLD), divided militant labor unions and established conservative, anti-communist ("free") unions who supported U.S. political and economic policies in the region (Barry and Preusch 1990; Morris 1967; Radosh 1969; Scott 1978). In addition, AIFLD representatives were involved in military coups against leftist governments in Brazil, Chile, and the Dominican Republic in the 1960s and 1970s (Radosh 1969; Herod 1997b). These machinat ions effectively undermined international labor solidarity for the next forty-five years.

\section{Cross-Border Labor Organizing in the 1990s 3}

However, the demise of the Cold War and the globalization of production have led labor activists and unions from developed and developing nations to begin working together. For example, in 1992, two independent unions, the U.S.-based United Electrical (UE) workers and the Mexican-based Authentic Workers Front (FAT), developed a "strategic organizing alliance" (Johnson 1994). The UE and FAT have provided each other with organizers and other forms of assistance (Davis 1995). Moreover, the U.S. garment workers union, UNITE (Union Needletrades, Industrial, and Textile Employees), in conjunction with AIFLD, has carefully worked with maquiladora workers in the Dominican Republic and Honduras (Fieldman 1996). In 1995, the first-ever maquila unions were founded and negotiated collective bargaining contracts in the Dominican Republic (Fieldman 1996; ICFTU 1996). Finally, labor rights and solidarity organizations, like the United States/Guatemala Labor Education Project (US/GLEP), Witness for Peace, the Campaign for Labor Rights, the Support Committee for Maquiladora Workers, and the National Labor Committee, have also been instrumental in the formation of maquila unions in Guatemala and Nicaragua, and in improving working conditions and wages in Mexico and El Salvador (Campaign for Labor Rights 1997; Coats 1996; Cook 1997; Pattee 1996; Rockenbach 1995). 


\section{Phillips Van-Heusen and Ford Cuautitlan}

These examples indicate there have been several "successful" cases of cross -border labor organizing. However, there have also been many "unsuccessful" cases of cross -border organizing. In this article I examine two different case studies--one successful, the other unsuccessful--of cross-border labor organizing. The first case involves Phillips VanHeusen (PVH) workers in Guatemala City, and the other Ford workers in Cuautitlan, Mexico.

In August 1997, after eight long years, PVH workers ratified the only contract in the Guatemalan maquiladora industry (US/GLEP Update \#20). International solidarity and assistance were critical elements of this campaign (Armbruster forthcoming). In contrast, in Cuautitlan, Ford workers have struggled for ten years for higher wages, better working conditions, and union democracy (La Botz 1992; Escobar 1997). The Ford Cuautitlan workers have received international support, but their demands have not been achieved (COT 1997). These two case studies and their different outcomes provide academics and activists who are interested in cross-border labor organizing and globalization with some important lessons.

\section{The Difficulties of Cross-Border Labor Organizing}

Despite the recent PVH victory and other successful cases, many academics and activists maintain that cross-border labor organizing is extremely difficult and nearly impossible. 4 These academics and activists contend there are four major factors, among others, that limit cross-border labor organizing. 5 First, the globalization thesis suggests that capital mobility, especially in the garment industry where production can be easily moved, has undermined the possibilities of cross-border labor organizing and that workers and labor unions have no capacity for agency or resistance (see Herod 1995, 1997a). For example, when confronted with labor rights violations and cross-border labor organizing campaigns, the Gap and Phillips Van-Heusen threatened to leave El Salvador and Guatemala respectively (Bounds 1997; Pattee 1996). Both companies eventually backed down, but other garment manufacturers have simply cut their contracts with their overseas producers and moved to new countries. $\underline{6}$

The second barrier restricting cross-border labor organizing is state repression (Dueñas 1997; Muñoz 1994). For instance, highly repressive military dictatorships previously controlled Guatemala, El Salvador, Brazil, Chile, and other Latin American nations for many years (Alves 1985; Dunkerly 1988; Jonas 1991; Petras and Morley 1975). These governments outlawed labor unions at various times, and many labor activists were jailed, beaten, and even killed in these countries. Decades of physical repression often produced small and weak labor movements in these nations. Under these cond itions the establishment of cross-border linkages with unions in repressive nations is extremely difficult (Muñoz 1994).

The third factor limiting cross-border labor organizing is corporatist state-labor relations (R. Gonzalez 1997; Lujan 1996; Martinez 1997; Muñoz 1994). The long-standing 
alliance between the Institutional Revolutionary Party (PRI) and the Confederation of Mexican Workers (CTM) is perhaps the best example of a corporatist state-labor relationship (La Botz 1992). The CTM and the PRI both supported the North American Free Trade Agreement (NAFTA) and have limited the establishment of independent and democratic labor unions for many years (French et al. 1996; La Botz 1992; Middlebrook 1995). The CTM's activities led some U.S. unions, like the UE, the Steelworkers, and the Teamsters, to develop closer ties with the FAT--a small, independent labor federation which opposed NAFTA (Lujan 1997; Martinez 1997). The FAT and several new dissident labor organizations, like the Foro, the May First Intersindical Movement, and the National Workers Union (UNT), have challenged the CTM's control of the Mexican labor movement (La Botz 1997). However, these new labor organizations have not displaced the CTM (La Botz 1997). The CTM remains a strong and influential force within the Mexican labor movement, and consequently, U.S. and Canadian unions have had limited success in initiating cross-border labor linkages with Mexican labor unions (French et al. 1996).

The long history of the AFL-CIO's Latin American affiliate, the American Institute for Free Labor Development (AIFLD), is the fourth barrier limiting cross-border labor organizing. AIFLD was established in 1962, and received corporate, CIA, and State Department funding for many years (Sims 1992). AIFLD undermined militant labor unions and established conservative pro-government unions that supported U.S. foreign and economic policies in many different nations (Armstrong et al. 1989; Barry and Preusch 1990; Cantor and Schor 1987; Morris 1967; Scott 1978; Spalding 1988a, 1988b, 1992; Weintraub and Bollinger 1987; Herod 1997b). For example, AIFLD was active in El Salvador in the 1980s (Spalding 1992). AIFLD divided labor federations that opposed their policies, bribed labor leaders, and supported El Salvador's labor rights record, even though military and death squad officials killed thousands of unionists (Americas Watch 1988; Armstrong et al. 1988). These activities, termed "trade union imperialism," have created lingering suspicions of the AFL-CIO in Latin America and are an important barrier to the establishment of cross-border labor linkages and international solidarity.

Interestingly, three of these four factors, capital mobility, state repression, and trade union imperialism, were present in the Phillips Van-Heusen case. Despite these barriers, cross-border labor organizing and the ratification of the only contract in the Guatemalan maquiladora industry were achieved. The PVH case then challenges established assumptions about the impossibility of cross-border labor organizing in the highly mobile garment industry, in a nation notorious for repression against labor unions, involving a labor federation who in the past received financial support from AIFLD. However, the Ford Cuautitlan case indicates there are some significant barriers that have limited crossborder labor organizing. These two cases and the differences between them are discussed below.

[Page 22] Journal of World-Systems Research 


\section{Methodology}

In this paper I describe and analyze the PVH and Ford Cuautitlan cases using in-depth interviews, newsletters, and other primary and secondary sources. In 1996 and 1997, I conducted interviews with academics, government officials, and representatives from the international garment workers trade secretariat (ITLGWF), UNITE, UAW, AIFLD, CTM, STECAMOSA, US/GLEP (see the appendix for a listing of these organizations), and many other organizations, in Guatemala, Mexico, and the United States. In the next two sections I describe the history of the Guatemalan labor movement and the emergence of the Guatemalan maquiladora industry. This overview is critical for understanding the context of the PVH case.

\section{The Guatemalan Labor Movement: Repression and Resistance}

The history of the Guatemalan labor movement is one of repression and resistance. In 1954, a U.S.-backed military coup overthrew the short-lived democratic government of Guatemala (Kinzer and Schlesinger 1982; Gleijeses 1991). The new military dictatorship quickly dismantled the burgeoning labor movement, and the main labor federation, the Confederacion de Trabajadores de Guatemala (CGTG) (Larrave 1975). Despite military repression, several labor federations, including the militant Confederacion Nacional de Trabajadores (CNT), were founded in the 1960s and 1970s (Larrave 1975). In 1976, a broad and unified labor and popular front, the Comite Nacional de Unidad Sindical (CNUS) was established (Albizures 1980). The CNUS was a broad-based labor organization that challenged the policies of the state and ruling elite (Albizures 1980). In addition, student, religious, and campesino organizations, like the Comite Unidad Campesina (CUC), also emerged in this period (Menchu 1984; Jonas 1991).

However, in the late 1970s and early 1980s, the CNT, CNUS, CUC, and other labor unions and popular organizations were virtually eliminated through arrests, disappearances, assassinations, and massacres. For example, CNUS lawyer Mario Lopez Larrave was assassinated in 1977, and 39 protestors, including 27 CUC activists, were burned inside the Spanish Embassy in 1980 (Menchu 1984). In addition, military agents captured and disappeared 27 CNT leaders on June 21, 1980, and on August 24, 1980 , another 17 CNT members were assassinated (Levenson-Estrada 1994). These repressive policies decimated the labor movement, and for the next several years, workers, labor activists, and some labor unions organized themselves in a clandestine and underground manner (Dueñas 1997; Robles 1997; Reed and Brandow 1996).

In the 1970s and 1980s, the Guatemalan military also adopted "scorched-earth" policies and killed thousands of Mayan Indians (Falla 1994; Manz 1988). Military and death squad officials claimed the Mayan population supported guerilla organizations, like the Guerilla Army of the Poor (EGP) and the Organization of the People in Arms (ORPA). 7 Some Mayan Indians joined these guerilla organizations, but many were innocent bystanders and were tortured and killed in the army's campaign of mas s terror (Harbury 1994; Jonas 1991; Montejo 1987). In this period alone, over 75,000 Guatemalans were killed, 440 villages were burned, and one million people were displaced (Manz 1987). 
The Guatemalan military killed and disappeared over 200,000 Guatemalans between 1954 and 1991 (Jonas 1991). These genocidal policies reinforced staggering levels of poverty, malnutrition, and inequality (Barry 1992).

Despite these overwhelming odds, Coca-Cola workers in Guatemala City resisted these policies and formed the Coca-Cola Company Workers' Union (STEGAC) in the 1970s (Albizures 1988; Levenson-Estrada 1994; Robles 1997). Company officials responded with force and killed eight Coca-Cola union members between 1978 and 1980 (Levenson-Estrada 1994). Coca-Cola workers and union members continued organizing, and obtained national and international solidarity from organizations, like CNUS, the International Union of Foodworkers (IUF), the Interfaith Center for Corporate Responsibility (ICCR), and Amnesty International (Gatehouse and Reyes 1987; Frundt 1987). These organizations initiated a corporate campaign against Coca-Cola which included "production stoppages and consumer boycotts in over fifty countries" (Frundt 1987a). These actions, combined with a year-long factory occupation, were successful, and Coca-Cola workers and union members obtained a collective bargaining agreement in 1985 (Frundt 1987). The Coca-Cola case illustrated the potential of cross-border labor organizing and provided academics and activists with some important lessons (LevensonEstrada and Frundt 1995).

[Page 23]

Journal of World-Systems Research

\section{Export-Led Development Policies and The Guatemalan Labor Movement}

The Coca-Cola case occurred in the context of an economic crisis. For many years Guatemala depended on stable prices for agricultural exports (Jonas 1991). However, fluctuating prices often created economic crises and high unemployment (Barry 1990; Jonas 1991). Therefore, in the 1970s, Guatemalan military and economic elites, along with officials from the U.S. Embassy and the Agency for International Development (AID), adopted a new development strategy that emphasized non-traditional exports and tourism (Jonas 1991; Petersen 1992). Guatemala's military and economic elites also repressed labor unions and provided foreign investors with low-wage labor, tax incentives, and other subsidies (Petersen 1992). Guatemalan and U.S. officials claimed these policies would create economic growth, and that Guatemala would follow the four East Asian "Tiger" economies of South Korea, Singapore, Taiwan, and Hong Kong, and become the "Jaguar" of Latin America (Jonas 1991; Petersen 1992).

However, Guatemala's new export-oriented development model was limited by the requirements of the U.S.-sponsored Generalized System of Preferences (GSP) (Petersen 1992). The GSP mandates that recipient nations protect internationally recognized worker rights provisions, like the right to organize and collectively bargain, in exchange for tariff exemptions on imports and development assistance (Petersen 1992). Nations that fail to protect worker rights policies can lose their GSP benefits, or they can be placed under 
"review" until they "take steps" to enforce these policies (Dorman 1989). Given these conditions, the Guatemalan military accepted the formation of a new labor federation, the Confederacion de Unidad de Guatemala (CUSG), in 1983 (Frundt 1995).

In its early years, CUSG cautiously adopted pro-government positions and accepted financial assistance from AIFLD (Alfaro 1997; Frundt 1995; Slaughter 1987). However, CUSG later embraced anti-government policies and briefly joined the militant, and nonAIFLD supported, Unidad Accion Sindical y Popular (UASP) (Frundt 1995). In addition, two other labor federations, the militant and independent Union Sindical de Trabajadores de Guatemala (UNSITRAGUA), and the Christian Democratic Confederacion General de Trabajadores de Guatemala (CGTG) were respectively established in 1985 and 1986 (Coj 1997; Dueñas 1997). UNSITRAGUA became one of the leading organizations of UASP, and provided CUC and other popular organizations with support (Barry 1990). CGTG mostly organized public sector employees, and did not join UASP in the late 1980s (Goldston 1989). CUSG, CGTG, UNSITRAGUA, and several other labor unions represented less than 3\% of Guatemala's labor force in the 1980s and 1990s (Doumitt 1996; Robles 1997).

\section{The Emergence of the Maquiladoras}

The adoption of the non-traditional export model, the passage of the GSP, and the election of Guatemala's first civilian president in over thirty years created the foundation for increased foreign investment in the mid-1980s (AVANSCO 1994; Dueñas 1997). In this period, a new non-traditional export industry, known as the maquiladoras, emerged. Maquiladoras are off-shore factories that produce garments for export markets-particularly the United States (Petersen 1992). In 1984, there were only six maquiladoras in Guatemala, but some sources indicate there are currently over 400 maquiladoras, employing nearly 100,000 workers (Grafico 1996). $\underline{8}$ Most maquila workers are young women who earn less than three dollars per day and who often work sixty or more hours per week (Casertano 1997; Cerigua 1994; Petersen 1992). One union activist stated that maquila workers are sometimes forced to take amphetamines to complete long workshifts (Galacia 1997). Many maquila workers labor inside locked warehouses where bathroom breaks are timed and their supervisors often verbally and physically harass them (Cerigua 1994; MJ Modas 1997; Salguero 1997). 2

Maquiladora workers have periodically formed unions in opposition to these poor working conditions and low wages. However, when confronted with unrest, many maquila owners simply fire their workers or close down (Casertano 1996; Coj 1997; Doumitt 1996). For example, UNSITRAGUA has organized fourteen unions, but only three still exist (Coj 1997).10 There is one other union in the maquiladora industry. This union is affiliated with CUSG and it is only one with a collective bargaining agreement (Alfaro 1997, US/GLEP Update \#20). This union's members work for Phillips VanHeusen, a U.S.-based manufacturer.

[Page 24]

Joumal of World-Systems Research 


\section{Phillips Van-Heusen}

Phillips Van-Heusen is one of the largest shirtmakers in the world and produces 300,000 dozen shirts per year in Guatemala (Human Rights Watch 1997: 47). PVH opened two factories, called CAMOSA I and CAMOSA II, in Guatemala City in 1988 (Petersen 1992).11 One year later, PVH began contracting out production to smaller factories, called "submaquilas," located in the nearby community of San Pedro, Sacatepequez (Petersen 1992). PVH also contracts out production to two other Guatemala City-based maquilas (Human Rights Watch 1997: 47). Over 70\% of PVH's 660 workers are young women who earn far less than the living wage--most earn 75 cents an hour, which is only half of what they need to raise their families above the poverty level (Casertano 1997). PVH has claimed that their workers receive higher than average wages and benefits, and that the company provides ergonomic working conditions (Petersen 1992; Bounds 1997).

\section{The Phillips Van-Heusen Workers' Movimiento (1989-1997)}

Despite the company's carefully crafted public image, PVH workers began organizing over unstable piece-rate prices, declining wages, and poor treatment from supervisors in 1989 (Petersen 1992). Over the next three years, PVH workers and activists were fired, harassed, and one union leader, Aura Marina Rodriguez, was shot and nearly killed (Coats 1991). However, the PVH workers eventually obtained union recognition in 1992. The newly recognized union, called STECAMOSA (Sindicato de Trabajadores de Camosa), won recognition after the United States/Guatemala Labor Education Project (US/GLEP), the International Ladies Garment Workers Union (ILGWU), the Amalgamated Clothing and Textile Workers Union (ACTWU), and several other U.S. unions filed a worker rights petition against the Guatemalan government under the Generalized System of Preferences (Coats 1991). The threat of losing these trading benefits created a "window of opportunity" and pressured the Guatemalan government into recognizing the first maquila union--STECAMOSA--in six years (Coats 1993). Despite this victory, PVH refused to negotiate with STECAMOSA since the union did not represent $25 \%$ of the workers as is required by the Guatemalan labor code (Coats 1993). The company's resistance weakened the union over the next several years (STECAMOSA 1996; Casertano 1996).

However, in June 1995, STECAMOSA became interested in initiating an "internal organizing" campaign (STECAMOSA 1996). Initially, the PVH workers' union contacted their federation, the tiny Guatemalan Textile Workers Federation (Casertano 1996). The textile workers federation, which is affiliated with CUSG, then requested assistance from the International Textile, Garment, and Leather Workers Secretariat (ITGLWF) (Coats 1996). ITGLWF is an international trade secretariat that coordinates the activities of national labor unions in the garment industry. The garment workers trade secretariat has a regional office in Latin America, called the Inter-American Textile and Garment Workers Federation (FITTIV). FITTIV, which had already been instrumental in the formation of 
maquila unions in the Dominican Republic and Honduras, responded to the union's request and sent a full-time organizer to work with STECAMOSA (Casertano 1996).

The PVH workers' union, FITTIV, US/GLEP, and the U.S. garment workers union, UNITE, then developed a "strategic cross-border labor organizing model" that included new organizing strategies, trade pressure, and consumer action. After extensive planning, the PVH workers conducted an "organizing blitz" in late August 1996 (Coats 1996; Hermanson 1997). The union successfully signed up over 100 members in an effort to reach the $25 \%$ level and begin contract negotiations (Coats 1996). After the blitz, the union determined it had attained the required $25 \%$ membership level, and filed a petition to negotiate. However, the company disputed the union's claim that it represented over $25 \%$ of all PVH workers, and refused to negotiate (Human Rights Watch 1997: 25). The Guatemalan Labor Ministry conducted an investigation on whether or not $25 \%$ of the PVH workers were union members. The Labor Ministry claimed it was "unable to determine the union's membership level" and closed the case in November 1996 (Human Rights Watch 1997: 35). However, the union's records clearly indicated that over $25 \%$ of PVH's workers were union members (Human Rights Watch 1997: 26).

[Page 25]

Journal of World-Systems Research

After three tense months, PVH, US/GLEP, and the PVH workers' union requested that Human Rights Watch conduct an independent investigation of the $25 \%$ issue (Human Rights Watch 1997: 2). PVH CEO Bruce Klatsky, who sits on Human Rights Watch's Board of Directors, agreed to negotiate if investigators determined the union reached the $25 \%$ level. Human Rights Watch determined over $25 \%$ of PVH's workers were union members, and PVH released a statement on March 11, 1997 promising to negotiate with the union (Human Rights Watch 1997: 4). In April 1997, contract negotiations between the PVH workers' union and PVH began (US/GLEP Update \#19). On August 14, 1997, after an eight-year struggle, PVH workers ratified the only contract in the maquiladora industry (US/GLEP Update \#20). The two-year contract includes provisions for an $11 \%$ wage increase in the first year, and $12.5 \%$ increase in the second year, subsidies for transportation, lunch, child care, grievance procedures, money for an off-site office, and the preservation of current employment levels "as long as basic productivity levels are met" (US/GLEP Update \#20).

\section{Strategic Cross-Border Labor Organizing and Lessons from the Phillips Van-Heusen $\underline{\text { Case }}$}

The PVH workers and their cross-border allies defied the conventional wisdom about cross-border organizing and produced a stunning victory. The crucial question is --how were they able to achieve this victory? There were five key elements of this campaign. First, as mentioned above, the PVH workers' union contacted the international garment workers secretariat who provided them with a full-time organizer from FITTIV. This 
organizer worked directly with the PVH workers' union and regularly discussed organizing issues with UNITE representatives (Hermanson 1997). The active involvement of this organizer and other forms of technical assistance from FITTIV were invaluable parts of this campaign.

The second key factor was the application of a new organizing model that had never been used before in the maquiladora industry (Coats 1996). Previously, maquila workers organized spontaneously or formed unions with very few members (Casertano 1997). In Guatemala, a union can be legally recognized with only twenty members (Pete rsen 1992). However, obtaining recognition often takes months and in the interim period many companies have fired union members or closed down production (Casertano 1997; Hermanson 1997). These factors explain the weaknesses of the existing maquila unions and the failure of past organizing efforts.

The PVH workers' union, FITTIV, and UNITE believed a strategic organizing model, which generated organizational strength and an active membership, would limit PVH's use of these traditional union-busting tactics. Therefore, STECAMOSA, FITTIV, and UNITE developed a clandestine labor organizing model and established a small group of union supporters within the factory (Hermanson 1997). These union supporters recruited new members and planned for months before launching an "organizing blitz" of PVH workers (Hermanson 1997). During the blitz, PVH union members conducted "house visits" of their fellow workers and signed up enough new members to reach the required $25 \%$ level (Casertano 1997). This strategy was designed to surprise company supervisors and avoid massive firings. Teresa Casertano (1997), explains this organizing model:

If you have a majority of workers signed up, the company cannot intimidate that many workers over the 30 -day recognition period. Also, after a union reaches the $25 \%$ level they can demand contract negotiations right away. So the union's strength, goals, and demands for recognition and contract negotiations depend on organizing a significant amount of workers.

Jeff Hermanson (1997), UNITE's Director of Organizing, contends that most crossborder labor organizing campaigns have adopted an "overt organizing model." In this model, workers organize themselves publicly and establish a large base of supporters. However, this strategy has created fear, intimidation, firings and very little support for unionization (Hermanson 1997). In these situations, labor, human rights, and religious organizations in the Untied States, and in other countries, have initiated consumer boycotts and letter-writing campaigns on behalf of fired maquiladora workers. However, these strategies have limitations. Hermanson (1997) maintains, "on-the-ground organizing, careful planning, and a strong membership base, along with these other strategies and tactics, are absolutely critical." The PVH case supports this perspective and illustrates the effectiveness of clandestine labor organizing models.

[Page 26]

Journal of World-Systems Research 
The third critical element of the PVH case was the involvement of solidarity and labor rights organizations like US/GLEP, Witness for Peace, Campaign for Labor Rights, NISGUA (Network in Solidarity With the Guatemalan People), and many other groups (Coats 1996). For instance, US/GLEP coordinated three days of grass-roots leafletting of major department stores in the United States, like JC Penney's, which purchases PVH products. These stores were leafletted during the Christmas holiday shopping season and on International Women's Day. These leafleting actions were designed to increase consumer awareness and put pressure on PVH to negotiate with STECAMOSA. These solidarity organizations, and the consumer pressure they created, were key aspects of the PVH campaign (US/GLEP Update \#18).

During the PVH campaign, US/GLEP raised the issue of GSP pressure again. In late 1996, Guatemala had been under GSP review for four years for labor rights violations, and many believed that the country's peace negotiations would lead to the lifting of the review. However, Guatemalan labor federations, US/GLEP, and several U.S. unions claimed that labor rights were still not protected and that the GSP review should be maintained. The PVH campaign affected the long-awaited GSP decision, and prompted U.S. Labor Department official, David Parker (1997), to state, "the Guatemalan Labor Ministry's and PVH's actions are factors in delaying the decision on GSP." This comment illustrates that US/GLEP effectively used trade pressure as "leverage" in their efforts to support the PVH workers' union. 12

The fifth strategic element of this campaign involved undermining PVH's "socially responsible" image. PVH CEO Bruce Klatsky has carefully cultivated a progressive image of PVH through his involvement with Human Rights Watch, Business for Social Responsibility, and the White House's Apparel Industry Partnership. However, when Human Rights Watch released its findings on the $25 \%$ issue, Klatsky realized he was trapped and the company began negotiations with STECAMOSA. US/GLEP, FITTIV, and the PVH workers' union realized PVH's corporate image was vulnerable and they skillfully used this point to their advantage.

These were the key elements of the PVH case--an active international trade secretariat, a new organizing model, a broad-based coalition of solidarity and labor rights organizations, consumer and trade pressure, a strong and active membership, and company vulnerability. The combination of these elements produced a remarkable victory for the PVH workers and the Guatemalan labor movement. The PVH case demonstrates the potential of "strategic" cross-border labor organizing. However, the Ford Cuautitlan case illustrates the barriers to cross-border labor organizing. In the following sections I briefly describe the Mexican labor movement and Mexico's deep economic crisis. This discussion situates the Ford Cuautitlan case in the broader context of widespread economic and social change in Mexico.

[Page 27] 


\section{The Mexican Labor Movement: The Persistence and Limitations of Corporatism}

The Confederation of Mexican Workers (CTM) has dominated the Mexican labor movement for the past sixty years (La Botz 1992; Middlebrook 1995). In the 1930s and 1940s, the Party of the Mexican Revolution (PRM) and its successor, the Institutional Revolutionary Party (PRI) recognized the CTM as the "official" representative of the labor movement and incorporated the CTM into the structure of both parties (Cockcroft 1983). This corporatist relationship between the CTM and the PRI has lasted into the 1990s. These corporatist state-labor relations have provided the CTM and PRI with mutual benefits. For instance, the CTM has often supported the PRI's political and economic policies like wage controls, peso devaluations, an d trade liberalization. In exchange, the PRI has provided the CTM and its officials with government positions and financial subsidies (Middlebrook 1995). The CTM and the PRI have also vigorously limited rank-and-file dissent and the emergence of democratic and independent labor unions through violence and intimidation. For instance, in the $1940 \mathrm{~s}$ and $1950 \mathrm{~s}$, the PRI and the Mexican military crushed militant strikes organized by the railroad, electrical, mining, and petroleum workers' unions (Alonso 1979; Carr 1992; La Botz 1988; Middlebrook 1995). The PRI and the CTM also purged leftists an communist labor leaders and installed new pro-government labor leaders, or charros, in these unions (La Botz 1988). The AFL, the CIO, and AIFLD's predecessor, the Inter-American Federation of Labor (ORIT), supported these policies and worked closely with the CTM during this period (Caulfield 1997).

[Page 28]

Journal of World-Systems Research

The CTM and the PRI have also controlled the labor movement through legal procedures and mechanisms. For example, the Mexican Constitution established the Boards of Conciliation and Arbitration to mediate labor disputes and conflicts (Carr 1976; La Botz 1992). The Boards (sometimes called the Juntas) include representatives from capital, labor, and the state (Middlebrook 1995). The juntas have the power to register labor unions and they can also declare strikes illegal or legal (Middlebrook 1995). PRI and CTM officials have served on these boards for years, and they have limited strikes and the registration of independent and democratic labor unions (although the PRI has occasionally favored other charro unions, like the Regional Confederation of Mexican Workers [CROM] and the Revolutionary Confederation of Workers and Peasants [CROC] in the registration process) (La Botz 1992; Middlebrook 1995). These legal machinations strengthened the CTM's control of the labor movement and limited the establishment of independent unions.

However, Mexico's corporatist state-labor relationship has often produced opposition movements within many labor unions and confederations. For instance, in the 1970s, a 
period of prolonged labor conflict (known as the insurgencia obrera) emerged and some independent and democratic labor unions were established (Carr 1991; De la Garza Toledo 1991). Presidential labor policies created a brief "political opening" for some of these movements. However, low wages, rising unemployment, and the CTM's antidemocratic practices also generated working-class discontent and unrest (De la Garza Toledo 1991; La Botz 1988). Automobile workers, electrical workers, and teachers organized these democratic labor movements (De la Garza Toledo 1991). For example, in the 1970s, a new democratic teachers' movement, known as the National Coordin ating Committee of Education Workers (CNTE), emerged within the National Union of Education Workers (SNTE) (Cook 1996). In addition, five automobile unions introduced democratic reforms and three of these unions (at Dina, Nissan, and Volkswagen) severed their ties with the CTM and joined the Independent Worker Unit (UOI) (Aguilar Garcia 1982; Middlebrook 1995; Roxborough 1984). Moreover, Rafael Galvan established the Democratic Tendency, which was a rank-and-file movement of electrical workers, within the Mexican Electrical Workers' Union (STERM) (La Botz 1988). Leftist organizations, like the Proletarian Line, the Mexican Workers' Party, and the Revolutionary Workers Party, influenced some of these labor organizations (Carr 1992).

In the late 1970s and early 1980s, conflicts between the CTM and the PRI also emerged (Middlebrook 1995). The PRI and the CTM clashed over the PRI's economic policies which generated rising inflation, high unemployment, and declining wages (Middlebrook 1995). The CTM initially opposed these policies and called on the PRI to improve wages and introduce price controls on basic commodities (Middlebrook 1995). The CTM also threatened to call general strikes if their demands were not achieved (Middlebrook 1995: 260). The PRI rejected the CTM's demands and supported other "official" labor confederations, like the CROC and CROM, which strongly embraced the PRI's economic policies. The PRI and CTM eventually resolved their differences. However, periodic disputes between the PRI and CTM emerged in the late 1980s and 1990s (Teichman 1996).

The establishment of democratic labor movements and the divisions between the PRI and the CTM indicate that Mexican state-labor relations are often complex. These democratic labor movements, and the emergence of the Foro, the May First Intersindical Movement, and National Workers Union (UNT), illustrate that the CTM and the PRI cannot completely control working-class mobilization and discontent. However, these new labor organizations are politically and ideologically divided, and they, along with democratic and independent unions, like the FAT, have not replaced the CTM (La Botz 1997). Corporatist state-labor relations in Mexico are relatively strong, and the PRI and the CTM can still effectively defeat democratic labor movements like the one at Ford Cuautitlan.

\section{Mexico's Economic Crisis}

Mexico's economic crisis and its adoption of export-oriented development policies are critical for understanding the Ford Cuautitlan case. In the late 1970s and early 1980s, Mexico's import-substitution model collapsed and its foreign debt exploded (Teichman 
1988). This deep economic crisis generated a prolonged period of economic and industrial restructuring. For instance, Mexico's political and economic elites adopted "structural adjustment policies" and privatized state-owned enterprises, introduced strict wage controls and currency devaluations, and limited social spending in the 1980s and 1990s (Teichman 1992). In addition, the PRI passed trade liberalization policies, like the North American Free Trade Agreement (NAFTA), provided foreign investors with various incentives, and emphasized export-oriented development policies (Moody 1995; Teichman 1992).

[Page 29]

Journal of World-Systems Research

U.S. government officials, international financial institutions, and foreign investors welcomed Mexico's turn towards neoliberalism and free trade. However, these neoliberal policies devastated the Mexican working class as wages dramatically declined, unemployment soared, workplace injuries and deaths increased, and class inequality widened (Lustig 1992; La Botz 1992; Moody 1995). For example, real wages fell by $50 \%$ between 1982 and 1991, and 25\% of all Mexicans were either unemployed or underemployed in 1996 (La Botz 1992, Mexican Labor News and Analysis 1997). These conditions produced working-class discontent and unrest. However, the CTM opposed and then supported the PRI's economic policies in a series of "solidarity pacts" (Middlebrook 1995). These pacts and the CTM's and PRI's control of the juntas limited labor militancy and the formation of independent labor unions and explain the labor movement's silence in this period of deep economic crisis (Middlebrook 1995).

The Mexican Automobile Industry and the Labor Movement, 1920s-1970s

Mexico's export-oriented development policies dramatically affected its automobile industry and shifted its orientation and focus. The history of Mexico's automobile industry is critical for understanding this shift. Mexico's automobile industry emerged in the 1920s and 1930s when Ford, General Motors (GM), and Fabricas Auto-Mex (a Mexican-owned firm that assembled Chryslers) established factories in the Federal District (Mexico City) (Arteaga 1993). These factories assembled automobiles from imported kits, but did not manufacture them (Arteaga 1993; Moreno 1988).

However, in the 1960s, Mexico passed legislative decrees that encouraged domestic vehicle manufacturing (Bennett and Sharpe 1985; Moreno 1988). These policies generated new levels of foreign investment in the automobile industry. For instance, Chrysler, GM, Ford, Nissan, and Volkswagen built new automobile factories in the states of Mexico, Morelos, and Puebla in the 1960s (Arteaga 1993; Bennett and Sharpre 1985). These factories manufactured cars for Mexico's domestic market and sparked the expansion of the auto parts industry (Arteaga 1993; Moreno 1988). 
The CTM controlled most of the labor unions in the automobile industry between the late 1930s and the early 1960s (although Ford's Mexico City workers challenged the CTM in the late 1940s, and GM's Mexico City workers joined the CROC in 1952) (Middlebrook 1995; Roxborough 1984). However, in the mid-1960s and 1970s, automobile workers resisted the CTM's anti-democratic policies, shopfloor alienation, and wage freezes, and established democratic and independent unions (Middlebrook 1995). For example, five automobile unions introduced democratic reforms, like the election of union officials, and three of these unions (Dina [a Mexican-owned company], Nissan, and Volkswagen) cut their ties with the CTM and joined the Independent Worker Unit (UOI) (Aguilar Garcia 1982; Middlebrook 1995; Roxborough 1984). Some of these unions acquired new personnel policies and grievance procedures, and in some cases, they limited the hiring of temporary workers (Middlebrook 1995). however, these unions did not obtain substantial wage increases (Middlebrook 1995).

\section{Mexico's New Automobile Factories and the CTM, 1980s-1990s}

In the 1980s, Mexico's automobile industry shifted its focus again. Falling wages eroded internal demand and limited domestic automobile production and sales (Middlebrook 1995; Moreno 1988). The Mexican government responded and passed new legislation that encouraged export-oriented production (Bennett and Sharpe 1985; Moreno 1988). For instance, Mexico lowered tariff barriers, reduced wages, and provided some automobile companies, like Ford, with tax incentives and subsidies for the establishment of new factories (Bennett and Sharpe 1985; Middlebrook 1995). Chrysler, GM, Ford, and Nissan embraced these policies and opened up new factories in central and northern Mexico (Arteaga 1993; Micheli 1994; Middlebrook 1995; Shaiken and Herzenberg 1987).

The major automobile companies realized that the democratic labor movements of the 1970s limited their decision making-power over production, promotion, and grievancerelated issues (Middlebrook 1995). Therefore, Ford, GM, Chrysler, and Nissan signed contracts with the CTM at their new factories which provided them with flexible work rules, work teams, fewer job categories, and greater power and influence over their workers (Middlebrook 1995). Automobile workers in these factories also worked longer hours and received lower wages and benefits than their counterparts in older automobile factories (Arteaga 1997; Micheli 1994). These contracts, along with the CTM's limitations on rank-and-file dissent, provided these companies with greater control over the production process and they began exporting hundreds of thousands of en gines and automobiles into the U.S. market in the late 1980s and 1990s (Arteaga 1993; Middlebrook 1995).

[Page 30]

Journal of World-Systems Research

\section{Ford Motor Company}


Mexico's adoption of export-led development policies and the restructuring of the automobile industry greatly affected Ford. For instance, in the 1980s, Ford closed two of its three Mexico City-based automobile factories that produced for the domestic market (Middlebrook 1995). However, in 1983 Ford built a new engine factory in Chihuahua, and, in 1986, Mazda and Ford opened up a new automobile plant in Hermosillo (Carrillo 1995; Micheli 1994). These two factories export nearly $100 \%$ of their products to the United States (Carrillo 1991; Micheli 1994). In addition, Ford Workers at these two factories are members of the local sections of the National Ford Workers Union, which is affiliated with the CTM (Middlebrook 1995). The CTM National Ford Workers Union negotiated contracts with Ford at these two plants that provided the company with flexible job categories, "just-in-time" production policies, work teams, and low wages (Carrillo 1995; Middlebrook 1995).

Ford has one other automobile factory, which is located in Cuautitlan, Mexico. The Cuautitlan factory was established in 1964, and primarily produced cars for Mexico's internal market until the 1980s (Carrillo 1995; De la Cueva 1997). However, a shrinking domestic market, along with tariff reductions and trade liberalization policies, prompted Ford to shift towards export-oriented production in Cuautitlan (Carrillo 1995). Thus, in the 1980s, Ford reduced wages and benefits, introduced flexible job policies, and integrated its Cuautitlan plant into the export care market (Carrillo 1995; La Botz 1992). Ford also reduced its number of employees in Cuautitlan from 7000 in 1981 to 3200 in 1987 (Middlebrook 1990: 53).

\section{The Ford Cuautitlan Workers' Struggle for Union Democracy (1987-1997)}

Ford Cuautitlan workers resisted the company's new policies. In the mid-1980s, Ford Cuautitlan workers enjoyed better than average salaries and working conditions (La Botz 1992). However, in July 1987, Ford refused to provide its Cuautitlan workers with an emergency $23 \%$ salary increase authorized by the federal government (Middlebrook 1990). Ford's position provoked a sixty-one-day strike (Middlebrook 1995). In late September 1987, Ford ended the strike, closed the factory, and fired all 3200 Cuautitlan workers (Becerril 1987; De la Cueva 1997). Ford rehired 2500 workers and reopened the factory several weeks later with a new contract (Middlebrook 1990). This new contract with the CTM "dramatically reduced salaries and benefits, compacted job titles, and eliminated whole job categories" (La Botz 1992: 148). Middlebrook (1995: 276) notes, "after October 1987, wage and bene fit levels at Cuautitlan were much closer to those at Ford's northern plants" (in Hermosillo and Chihuahua).

A new series of protests and conflicts emerged in Cuautitlan two years after the factory reopened. In 1989, the General Secretary of the CTM National Ford Workers Union, Lorenzo Vera, was replaced and the CTM appointed a new general secretary, Hector Uriate (Escobar 1997). A group of Cuautitlan workers, called the Ford Workers Democratic Movement (FWDM), challenged this appointment and demanded a democratic local union election (Escobar 1997). A local election was scheduled and FWDM representatives won and gained control of the local union (De la Cueva 1997). FWDM members, some of whom were active in the 1987 strike and in earlier protest, 
called for higher wages and benefits, and challenged the CTM's control of the National Ford Workers Union (De la Cueva 1997; La Botz 1992).

However, in June 1989, the CTM pressured Ford into firing the local union's executive committee members (La Botz 1992; Escobar 1997). The Cuautitlan workers responded with demonstrations and hunger strikes and continued organizing (Escobar 1997). However, Ford did not rehire the fired executive committee members (De la Cueva 1997). In December 1989, Ford reduced the annual Christmas bonus of its workers (La Botz 1992). This decision mobilized the Cuautitlan workers and they organized an occupation of the factory and demanded their "full bonus, the rehiring of the executive committee members, and the right to elect their own union leaders" (La Botz 1992: 149). The Ford Cuautitlan workers also met with CTM General Secretary Fidel Velazquez who promised to hold democratic local and national union elections (Escobar 1997; La Botz 1992). However, these elections were never held (Escobar 1997).

[Page 31]

Journal of World-Systems Research

The plant occupation turned violent on January 8, 1990. Raul Escobar (1997), one of the leaders of the FWDM, describes the situation on that morning:

- When the workers arrived at six A.M. they discovered 250 CTM pistoleros (thugs) inside the factory. The thugs ordered the workers to work and threatened to shoot them. The workers [there were approximately 2500 workers inside the factory at that moment] grabbed some tools and surrounded the CTM thugs, but they took out their guns and shot and killed one worker, Cleto Nigmo, and injured eleven others.

Ford officials paid the CTM pistoleros, and the government failed to protect the Cuautitlan workers inside the factory (La Botz 1992). This incident clearly revealed the active collusion between Ford, the CTM, and the PRI, and illustrated the difficulties of establishing democratic local unions.

In the aftermath of this violence, Cuautitlan workers received support from Ford workers in Chihuahua and Hermosillo and other unions in Mexico (De la Cueva 1997). The Cuautitlan workers also received international solidarity from United Auto Workers (UAW) Local 879 (St. Paul, Minnesota) members who organized a Trinational Workers Justice Day on the one-year anniversary of Nigmo's death (Moody and McGinn 1992). On January 8, 1991, Ford workers from various plants in Mexico, Canada, and the United States wore black ribbons honoring Cleto Nigmo (De la Cueva 1997). The Fo rd Cuautitlan workers welcomed this assistance, but the CTM still retained its tight control over the local union. 
The CTM's repressive activities led the Cuautitlan workers to file a petition to change their union affiliation to the Revolutionary Workers Confederation (COR) (De la Cueva 1997). The COR is another "official" labor confederation affiliated with the PRI and the Labor Congress (CT). A union election was conducted on June 3, 1991, and the CTM won by a thin margin (Middlebrook 1995). However, a committee of observers, which included representatives from UAW Local 879, the Canadian Auto Workers (CAW), and other labor and human rights organizations, discovered numerous electoral irregularities (La Botz 1992: 157-158). Hector de la Cueva, director of the Center for Research and Union Advising (CILAS), and a former Ford Cuautitlan worker, described some of these violations:

The election occurred inside the factory, while the workers were "on the line" working. Each worker voted in front of company officials, the police, and the CTM. Ford also brought in non-workers into the factory to vote. The result was that the CTM won by a very small margin--it was very close, but it was still not a legitimate election.

[Page 32]

Journal of World-Systems Research

The Cuautitlan workers called for new elections, but they were never held (La Botz 1992). The CTM remained in control of the local union.

In August 1996, local CTM union elections were held again at the Ford Cuautitlan plant. Nine different CTM slates qualified for the ballot, but the FWDM's slate (called the Brown Slate) was removed from the ballot (De la Cueva 1997). CTM National Ford union officials claimed that the FWDM's activities undermined the CTM's legitimacy and that international unions influenced the FWDM (Valenzuela 1997). The FWDM, fearing further violence and electoral fraud, invited labor unions and human rights and popular organizations to observe the election (Working Together Newsletter 1997). These organizations formed the Cleto Nigmo Trinational Observers Committee (COT 1997). Union members from the Canadian Auto Workers (CAW) and UAW Local 879 and UAW Region 1A (located in Michigan) served on the committee (COT 1997).

The CTM won the local union election and excluded the Trinational Observers Committee from observing the electoral process (R. Gonzalez 1997). The committee challenged the CTM's decision and the election results and filed a complaint with the Boards of Conciliation and Arbitration (Calderon 1996a). However, the Juntas claimed the election was an "internal union affair" and refused to hear the case (Calderon 1996b).

Nonetheless, members of the trinational committee interviewed more than 150 Ford Cuautitlan workers and discovered that many workers believed that the Brown Slate should have been on the ballot (R. Gonzalez 1997). Rodridgo Gonzalez, a member of the 
trinational delegation and a researcher with Centro de Reflexion y Accion Laboral (CEREAL) summarized the workers' feelings about the election:

Many workers were upset because the cafe planilla (brown slate) was left off the ballot. But, many workers also stated they were afraid to talk to the committee's members because they feared they would be fired.

In addition, many workers reported there was no secret ballot, and that they voted in front of CTM officials (R. Gonzalez 1997). These accounts indicate the CTM intimidated the Cuautitlan workers and that the CTM successfully manipulated the outcome of the election (Calderon 1996b). La Botz and Guerrero (1996: 5) describe the consequences of the 1996 election, "these recent events represent a defeat for union democracy and a victory for corporatism." However, these events also illustrate the difficulties of crossborder labor organizing.

\section{The Ford Cuautitlan Case and Cross-Border Labor Organizing}

Mexico's neoliberal and export-led development policies depend on strict labor control, low wages, and working-class fragmentation. The Ford Cuautitlan democratic workers movement for higher wages (most workers currently earn $\$ 1.50$ - $\$ 2$ per hour), better working conditions, union democracy, and the development of cross-border labor linkages with U.S. and Canadian unions challenged these policies. A democratic labor movement, even at the local level, seriously threatened the CTM's dominance, Mexico's stable investment climate, and Ford's competitive position in the global economy. For these reasons, the Ford Workers Democratic Movement was crushed on several different occasions. The Ford Cuautitlan case illustrates that corporatist state-labor relations not only limited the establishment of a democratic local union, but also limited the establishment of a democratic local union, but also restricted cross-border labor organizing in the automobile industry.

[Page 33]

Journal of World-Systems Research

The Cuautitlan case also indicates the UAW has not fully embraced cross-border organizing. Within the UAW, some UAW locals and regions have actively supported cross-border labor organizing and have provided the Cuautitlan workers with international solidarity. For instance, UAW Local 879 and the UAW Region 1A International Labor Solidarity Network have worked carefully with the Ford Cuautitlan workers over the last six years (Markell 1996). UAW Local 879 and the FWDM have even signed a formal "solidarity agreement" which calls for worker exchanges, information-sharing (on wages, working conditions, and Ford company policies) and Local 879's partial funding of one full-time FWDM organizer (Working Together Newsletter 1994). 
The UAW has not supported nor condemned Local 879 or Region 1A for their activities (Beckman 1997; Markell 1996). However, the UAW has criticized the CTM and Ford for their collusion in repressing the Ford Workers Democratic Movement (Beckman 1997). Yet, the UAW has not become directly involved in the Cuautitlan case. Steve Beckman (1997), UAW International Economist, explains the union's positions on the Ford Cuautitlan case and cross-border labor organizing:

The union has a very strained institutional relationship with the CTM and this prevents the UAW from intervening in local union matters. The CTM and the UAW distrust each other, but we cannot interfere in local disputes. Cross-border organizing requires a set of opportunities that do not currently exist in Mexico. The UAW has its own set of priorities right now and cross-border organizing is among them, but it competes with other issues as well.

These statements indicate that the UAW has adopted cautious policies towards the FWDM and cross-border labor organizing. However, some Local 879 and Region $1 \mathrm{~A}$ members have criticized this approach. These UAW (some of whom previously or currently belonged to New Directions, a dissident caucus within the UAW) members favor working directly with grass-roots, democratic labor movements in Mexico and they contend that cross-border labor organizing is critical for improving wages and working conditions for Mexican and U.S. auto workers. 13 These internal union conflicts and differences within the UAW have also limited cross-border labor organizing in the automobile industry.

\section{Discussion}

The theoretical literature contends that cross-border labor organizing is limited by capital mobility, state repression, corporatist state-labor relations, and trade union imperialism. Three of these four factors were present in the PVH case, but cross-border labor organizing and the ratification of a collective bargaining agreement were achieved. However, the Ford Cuautitlan case demonstrates the limitations of cross-border organizing. The following sections analyze the relationship between these two cases and the theoretical literature.

[Page 34]

Journal of World-Systems Research

The PVH case illustrated that structural barriers, like capital mobility, state repression, and trade union imperialism, contained their own specific limitations. For instance, PVH's emphasis on preserving its "socially conscious" image limited the threat and possibility of capital mobility. In addition, the relative decline in violence and repression in Guatemala has created some "breathing space" for the Guatemalan labor movement. This space enabled UNITE, US/GLEP, and the international garment workers trade secretariat to establish linkages with the PVH workers' union. Lastly, the PVH workers' 
union is affiliated with CUSG, and CUSG previously received funding from AIFLD (Frundt 1995). However, CUSG adopted its own positions, and some were critical of U.S. economic and foreign policy (Frundt 1995). In addition, AIFLD was involved in the establishment of maquila unions in Honduras and the Dominican Republic over the last several years (ICFTU 1996). Moreover, the AFL-CIO recently closed down AIFLD and created the new American Center for International Labor Solidarity (ACILS). AFL-CIO President John Sweeney appointed Barbara Shailor, a long-time critic of AIFLD's policies, as Director of ACILS (Working Together 1997). AIFLD's recent activities and the emergence of the ACILS open up new possibilities for U.S. and Latin American labor unions that are interested in cross-border organizing, and indicate that the long history of trade union imperialism may finally be waning.

The PVH workers' union, US/GLEP, FITTIV, and UNITE developed a "strategic" crossborder labor organizing model that exploited these structural weaknesses. This model included the following elements--an active international trade secretariat, new organizing strategies and tactics, trade and consumer pressure, the involvement of solidarity and labor rights organizations, and the manipulation of PVH's corporate image. The combination of these elements produced a stunning victory for the PVH workers and their cross-border labor allies.

The Ford Cuautitlan case also demonstrated that capital mobility did not limit crossborder organizing. Ford closed down its Cuautitlan factory in 1987, but never moved to another country. In addition, AIFLD was never involved in the Ford Cuautitlan case. Therefore, trade union imperialism had no impact on the outcome of this specific case. However, the CTM, the Mexican government, and Ford collaborated and repressed the Ford Workers Democratic Movement and their demands for union democracy, higher wages, and the establishment of cross-border labor linkages with U.S. and Canadian unions. The CTM National Ford Workers Union remains in control of the local union and they have not developed ties with the UAW, the CAW, or any grass-roots network of auto workers. The Ford Cuautitlan case demonstrates that corporatist state-labor relations limited union democracy and cross-border labor organizing in the automobile industry.

There is one other factor that affected the outcome of the Ford Cuautitlan case. Internal conflicts and differences within the UAW prevented the union from acting as an effective agent and limited cross-border labor organizing in the automobile industry. A more committed and unified UAW might have generated a more favorable outcome for the Ford Cuautitlan workers. UNITE's involvement in the PVH case, and the UAW International's lack of participation in Ford Cuautitlan case, indicate that a union's "level of commitment" also affects the possibilities of cross-border labor organizing. 14

Corporatist state-labor relations and internal conflicts within the UAW limited the possibilities for union democracy and cross-border labor organizing in the Ford Cuautitlan case. However, there are three additional reasons that explain why the Ford Cuautitlan workers were unsuccessful. First, the International Metal Workers Federation (IMF), the international trade secretariat for automobile and metal workers, was not involved in this case. The PVH case demonstrated that international trade secretariats can 
be effective. Second, there were no solidarity and labor rights organizations like US/GLEP that assisted the Ford Cuautitlan workers on a permanent basis. Most solidarity and labor rights organizations are focused on Central America and the garment industry. A new labor rights organization that emphasized Mexico and the automobile industry could be helpful in future campaigns. Third, the Ford Cuautitlan workers never attacked the company's image. The PVH and Gap cases have illustrated a corporation's public image is often vulnerable to media and consumer campaigns (Armbruster forthcoming; Pattee 1996). These three factors were instrumental in the PVH campaign, but they were not present in the Ford Cuautitlan case.

[Page 35]

Journal of World-Systems Research

\section{$\underline{\text { Summary }}$}

Cross-border labor organizing is very complex. The PVH case demonstrates that "strategic" cross-border labor organizing models can be effective even in the highly mobile garment industry and in a nation with a long history of labor repression. In contrast, the Ford Cuautitlan case demonstrates that corporatist state-labor relations and internal union conflicts have limited cross-border labor organizing in the automobile industry. These two case studies and their different outcomes provide academics and activists with some valuable lessons.

However, these two case studies also have broader implications. On a wider theoretical level, these two case studies illustrate the complex relationship between structure and agency. Most theories of cross-border labor organizing contend that structural barriers, like capital mobility or state repression, are so powerful that agency and social change are inconceivable. The Ford Cuautitlan case demonstrates that structural barriers did limit cross-border labor organizing. However, the PVH case indicates that structural factors have their own specific limitations. These limitations provided the PVH workers and their cross-border allies with an "opening" and they developed a strategic cross -border labor organizing model. These structural weaknesses and this new cross -border labor organizing model transformed the PVH workers into actors and makers of history. These two case studies illustrate that structures do not necessarily determine outcomes, and they indicate that a nuanced analysis of the relationship between structure and agency is critical for studies of cross-border labor organizing.

Cross-border labor organizing is still relatively new. The PVH case illustrates that crossborder labor organizing is possible, but the Ford Cuautitlan case demonstrates that there are some significant barriers that have limited cross-border labor organizing. These two case studies indicate that the adoption of "strategic" cross-border labor organizing models and the struggle for committed and democratic labor movements are critical for future cross-border labor organizing activities. 
[Page 36]

Journal of World-Systems Research

\section{ABBREVIATIONS}

ACILS American Center for International Labor Solidarity

AFL-CIO American Federation of Labor-Congress of Industrial Organizations

AIFLD American Institute for Free Labor Development

AUCCTU All-Union Central Council of Trade Unions

CAW Canadian Auto Workers

CEREAL Center of Reflection and Labor Action

CGTG General Confederation of Guatemalan Workers

CIA Central Intelligence Agency

CILAS Center for Labor Research and Union Advising

CNT National Center of Workers

CNUS National Committee on Trade Union Unity

COT Cleto Nigmo Trinational Observers Committee

CROC Revolutionary Confederation of Mexican Workers and Peasants

CROM Regional Confederation of Mexican Workers

COR Revolutionary Workers Confederation

CT Labor Congress

CTM Mexican Confederation of Workers

CUC Committee on Campesino Unity 
[Page 37]

Journal of World-Systems Research

CUSG Confederation of Guatemalan Trade Union-Unity

FAT Authentic Workers Front

FITTIV Inter-American Textile and Garment Workers Federation

FWDM Ford Workers Democratic Movement

GSP Generalized System of Preferences

ICFTU International Confederation of Free Trade Unions

ITGLWF International Textile, Garment, and Leather Workers Federation

NAFTA North American Free Trade Agreement

ORIT Inter-American Regional Organization of Workers

PRI Institutional Revolutionary Party

PRM Party of the Mexican Revolution

STECAMOSA Camosa Workers' Union

UASP Labor and Popular Action Unity

UAW United Auto Workers

UE United Electrical Workers

UNITE Union of Needletrades, Industrial, and Textile Employees

UNSITRAGUA Trade Union-Unity of Guatemalan Workers

UNT National Workers Union

UOI Independent Worker Unit

US/GLEP United States/Guatemala Labor Education Project

WFTU World Confederation of Trade Unions 
WTO World Trade Organization

$\underline{\text { References }}$

Articles, Books, and Presentations

Aguilar, Jaiver Garcia, 1982. La Politica Sindical en Mexico: Industria del Automovil. Mexico City: Ediciones Era.

Albizures, Miguel Angel. 1980. "Struggles and Experiences of the Guatemalan Trade Union Movement," Latin American Perspectives 7(2-3): 145-159.

[Page 38]

Journal of World-Systems Research

. 1988. Tiempo de Sudor y Lucha. Guatemala: Local Edition.

Alexander, Robin and Peter Gilmore. 1994. "The Emergence of Cross-Border Labor

Solidarity," NACLA: Report on the Americas 28(1): 42-48.

Alonso, Antonio. 1979. El Movimiento Ferrocarrilero en Mexico, 1958-1959. Mexico

City: Ediciones Era.

Alves, Maria Helena Moreira. 1985. State and Opposition in Military Brazil. Austin: University of Texas Press.

Americas Watch. 1988. Labor Rights in El Salvador. New York: Americas Watch.

Armbruster, Ralph. 1995. "Cross-National Labor Organizing Strategies," Critical Sociology 21(2): 77-91.

[Page 39]

Journal of World-Systems Research

. 1998. Globalization and Cross-Border Labor Organizing in the Garment and Automobile Industries. Ph.D. Dissertation. University of California, Riverside.

. forthcoming. "Cross-Border Labor Organizing in the Garment Industry: The Struggle of Guatemalan Maquiladora Workers at Phillips Van-Heusen," in Latin American Perspectives. 
Armstrong, Robert, Henry Frundt, Hobart Spalding, and Sean Sweeney. 1988. Working Against us: AIFLD and the International Policy of the AFL-CIO. New York: NACLA.

Arteaga, Arnulfo. 1993. "La Reestructuracion de la Industria Automotriz en Mexico y sus Repercusiones en el Viejo Nucleo Fabril," in Proceso de Trabajo y Relaciones Laborales en la Industria Automotriz. edited by Arnulfo Arteaga. Mexico City: UAM- Iztapalapa.

AVANSCO. 1994. El Significado de la Maquila en Guatemala. Cuaderno de Investigacion, No. 10.

Barry, Tom. 1990. Inside Guatemala. Albuquerque: Resource Center.

Barry, Tom and Deb Preusch. 1990. AIFLD in Latin America: Agents as Organizers. Albuquerque: Resource Center.

Becerril, Andrea. 1987. "Firman Acuerdo de Liquidacion de 3 mil 200 obreros de Ford," La Jornada, September 20: 9.

Bennett, Donald and Kenneth Sharpe. 1985. Transnational Corporations Versus the State: The Political Economy of the Automobile Industry. Princeton: Princeton University Press.

Bluestone, Barry and Bennett Harrison. 1982. The Deindustrialization of America. New York: Basic Books.

Bonacich, Edna, Lucie Cheng, Norma Chinchilla, Nora Hamilton, and Paul Ong. 1994. Global Production: The Apparel Industry in the Pacific Rim. Philadelphia: Temple University Press.

Bounds, Wendy. 1997. "Critics Confront a CEO Dedicated to Human Rights," Wall Street Journal, February 24: B1.

Brecher, Jeremy and Tim Costello. 1994. Global Village or Global Pillage: Economic Reconstruction From the Ground-Up. Boston: South End Press.

Browne, Harry and Beth Sims. 1993. Runaway America: US Jobs and Factories on the Move. Albuquerque: Resource Center.

Calderon, Judith. 1996a. "Demandan Anular Eleccines en Ford Cuautitlan," La Jornada, August 16:10.

. 1996b. "Decide la JFCA no Intervenir en el Conflicto Sindical de Ford," La Jornada, September 24: 18.

Cantor, Daniel and Juliet Schor. 1987. Tunnel Vision: Labor, the World Economy, and Central America. Boston: PACCA Series, South End Press. 
[Page 40]

Joumal of World-Systems Research

Carr, Barry. 1976. El Movimiento Obrero y La Politica en Mexico. Mexico City:

Ediciones Era.

1992. Marxism and Communism in Twentieth-Century Mexico. Lincoln: University of Nebraska Press.

Carrillo, Jorge V. 1995. "Flexible Production in the Auto Sector: Industrial

Reorganization at Ford-Mexico," World Development 23(1): 87-101.

Caulfield, Norman. 1997. "Mexican State Development Policy and Labor

Internationalism, 1945-1958," International Review of Social History 42: 45-66.

Cerigua. 1994. Maquilas in Guatemala: Ladder to Development or Over-exploitation?

Guatemala City: Cerigua.

Coats, Stephen. 1991. "PVH Workers Organize," Report on Guatemala 12(4): 8-9.

. 1993. "Maquila Workers Campaign: Success Raises Questions," Report on Guatemala 14(2) 13-15.

. 1996. "Taking on PVH: Maquila Workers Fight For Contract," Report on Guatemala 17(4): 6-7, 12-13.

Cockcroft, James. 1983. Mexico: Class Formation, Capital Accumulation, and the State. New York: Monthly Review Press.

Cook, Maria Lorena. 1996. Organizing Dissent: Unions, the State, and the Democratic Teachers' Movement in Mexico. University Park: Penn. St. Press.

. 1997. "Cross-Border Labor Solidarity," Dissent Winter: 49.

Davis, Terry. 1995. "Cross-Border Organizing Comes Home," Labor Research Review 23: $23-29$.

De la Garza Toledo, Enrique. 1991. "Independent Trade Unionism in Mexico: Past Developments and Future Perspectives," in Unions, Workers, and the State in Mexico, edited by Kevin Middlebrook. San Diego: Center for U.S.-Mexican Studies.

[Page 41]

Journal of World-Systems Research 
Deyo, Frederic. 1989. Beneath the Miracle: Labor Subordination in the New Asian Industrialism. Berkeley: University of California Press.

Dorman, Peter. 1989. "Worker Rights and US Trade Policy: An Evaluation of Worker Rights Conditionality Under the Generalized System of Preferences." Washington DC: Department of Labor.

Dreiling, Michael. 1997. "Forging Intermovement Alliances in the Struggle Against NAFTA: Structure and Strategy for Labor and Environmentalism," Paper presented at the Annual Meeting of the American Sociological Association. Toronto, Canada.

Dunkerly, James. 1988. Power in the Isthmus: A Political History of Modern Central America. London: Verso.

Emmanuel, Arrighi. 1970. "The Delusions of Internationalism," Monthly Review 22(2): 13-18.

Falla, Ricardo, 1994. Massacres in the Jungle: Ixcan, Guatemala, 1975-1982. Boulder: Westview Press.

Figueroa, Hector. 1996. "In the Name of Fashion: Exploitation in the Garment Industry," NACLA: Report on the Americas 29(4): 34-40.

[Page 42]

Journal of World-Systems Research

French, John, Jefferson Cowie, and Scott Littlehale. 1996. Labor and NAFTA: A

Briefing Book. Prepared for Labor, Free Trade, and Economic Integration in the Americas: National Union Responses in a Transnational World Conference. Duke University.

Frundt, Henry. 1987. Refreshing Pauses: Coca-Cola and Human Rights in Guatemala. New York: Praeger.

. 1995. "AIFLD in Guatemala: End or Beginning of a New Regional Strategy?" Social and Economic Studies 44(2-3): 287-319.

. 1996. "Trade and Cross-Border Labor Strategies in the Americas," Economic and Industrial Democracy 17: 387-417.

Gatehouse, Mike and Miguel Angel Reyes. 1987. Soft Drink, Hard Labor: Guatemalan Workers take on Coca-Cola. London: Latin American Bureau. 
Glejieses, Piero. 1991. Shattered Hope: The Guatemalan Revolution and the United

States. Princeton: Princeton University Press.

Goldston, James. 1989. Shattered Hope: Guatemalan Workers and the Promise of

Democracy. Boulder: Westview Press.

Grafico. 1996. "Maquila: Fabrica de empleos o atropellos." June 18: 15.

Greider, William. 1997. One World, Ready or Not: The Manic Logic of Global Capitalism. New York: Simon and Schuster.

Harbury, Jennifer. 1994. Bridge of Courage: Life Stories of the Guatemalan Companeros and Companeras. Monroe, ME: Common Courage Press.

Hart-Landsberg, Martin. 1993. The Rush To Development: Economic Change and Political Struggle in South Korea. New York: Monthly Review Press.

Haworth, Nigel and Harvie Ramsey. 1988. "Workers of the World Undermined: International Capital and Some Dilemmas in Industrial Democracy," in Trade Unions and the New Industrialization of the Third World, edited by Roger Southall. London: Zed Books.

Henwood, Doug. 1996. "Post-What?" Monthly Review 48(4): 1-11.

Herod, Andrew. 1995. "The Practice of International Labor Solidarity and The Geography of the Global Economy," Economic Geography 71: 341-363.

. 1997a. "From a Geography of Labor to a Labor Geography: Labor's Spatial Fix and the Geography of Capitalism," Antipode 29(1): 1-31.

. 1997b. "Labor as an Agent of Globalization and as a Global Agent," in Spaces of Globalization: Reasserting the Power of the Local, edited by Kevin Cox. New York: Guilford Press.

Human Rights Watch. 1997. Corporations and Human Rights: Freedom of Association in a Maquila in Guatemala. New York: Human Rights Watch.

ICFTU. 1996. Behind the Wire: Anti-Union Repression in Export Processing Zones. Brussels: ICFTU.

[Page 43]

Joumal of World-Systems Research 
Jonas, Susanne. 1991. The Battle for Guatemala: Rebels, Death Squads, and U.S. Power. Boulder: Westview Press.

Kamel, Rachael. 1990. The Global Factory. Philadelphia: American Friends Service Committee.

Kinzer, Stephen and Stephen Schlesinger. 1982. Bitter Fruit: The Untold Story of the American Coup in Guatemala. New York: Doubleday.

La Botz, Dan and Julio Cesar Guerrero. 1996. "Union Democracy Movement Barred From Ballot at Ford-Mexico Plant," Labor Notes October: 5.

La Botz, Dan. 1988. Crisis of Mexican Labor. New York: Praeger.

1992. Mask of Democracy. Boston: South End Press.

. 1994. "Making Links Across the Border," Labor Notes August: 7-10.

1997. "Mexico: Reform, Rebellion, and Revolution," Talk Presented at the University of California, Riverside. October 24.

Larrave, Mario Lopez. 1976. Breve Historia del Movimento Sindical Guatemalteco.

Guatemala City: Editorial Universitaria, Coleccion Popular.

Levenson-Estrada, Debroah. 1994. Trade Unionists Against Terror: Guatemala City 1954-1985. Chapel Hill: University of North Carolina Press.

Levenson-Estrada, Debroah and Henry Frundt. 1995. "Toward a New Inter-nationalism," NACLA: Report on the Americas 28(5): 16-21.

Lorwin, Lewis. 1953. The International Labor Movement. New York: Harper.

Manz, Beatriz. 1988. Refugees of a Hidden War. Albany: SUNY Press.

[Page 44]

Journal of World-Systems Research

Menchu, Rigoberta. 1984. I, Rigoberta Menchu. London: Verso.

Micheli, Jordy. 1994. Nueva Manufactura, Globalizacion, y Produccion De Automoviles en Mexico. Mexico City: UNAM. 
Middlebrook, Kevin. 1990. "Restructuracion industrial y Politica Sindical en la Industria Automotriz Mexicana," in La Insercion de Mexico en la Cuenca del Pacifico (Volumen II), edited by Alejandro Alvarez and John Borrego. Mexico City: UNAM.

1995. The Paradox of Revolution: Labor, the State, and Authoritarianism in Mexico. Baltimore: Johns Hopkins University Press.

[Page 45]

Journal of World-Systems Research

Montejo, Victor. 1987. Testimony: Death of a Guatemalan Village. Willimantic, CT: Curbstone Press.

Moody, Kim. 1988. An Injury to All: The Decline of American Unionism. London: Verso.

. 1995. "NAFTA and Corporate Redesign of North America," Latin American Perspectives 22(1): 95-116.

Moody, Kim and Mary McGinn. 1992. Unions and Free Trade: Competition or Solidarity? Detroit: Labor Notes.

Moreno, Juan Carlos. 1988. Mexico's Motor Vehicle Industry in the 1980s. International Employment Policies, Working Paper No. 21. Geneva: International Labor Organization.

Morris, George. 1967. The CIA, the AFL-CIO, and American Foreign Policy. New York: International Publishers.

Olle, Werner and Wolfgang Scholler. 1987. "World Market Competition and Restrictions Upon International Trade Union Policies," in International Labour and The Third World, edited by Rosalind Boyd, Robin Cohen, and Peter Gutkind. Aldershot: Avebury.

Pattee, John. 1996. "'Gapatistas Win a Victory'," Labor Research Review 24: 77-86.

Payeras, Mario. 1983. Days of The Jungle: The Testimony of a Guatemalan Guerrillero, 1972-1976. New York: Monthly Review Press.

Petersen, Kurt. 1992. The Maquiladora Revolution in Guatemala. New Haven: Schell Center for Human Rights, Yale Law School.

Petras, James and Morris Morley. 1975. The United States and Chile: Imperialism and the Overthrow of the Allende Government. New York: Monthly Review Press. 
Ping, Li. 1990. A Moment of Truth: Workers' Participation in China's 1989 Democracy Movement and the Emergence of Independent Unions. Hong Kong: Asia Resource Monitor Center (ARMC).

Radosh, Ronald. 1969. American Labor and United States Foreign Policy. New York: Random House.

[Page 46]

Journal of World-Systems Research

Reed, Thomas and Karen Brandow. 1996. The Sky Never Changes: Testimonies from the Guatemalan Labor Movement. Cornell: ILR Press.

Rockenbach, Leslie. 1995. Justice in the Maquiladoras. Master's Thesis. New York University--Buffalo.

Roxborough, Ian. 1984. Unions and Politics in Mexico: The Case of the Automobile Industry. Cambridge: Cambridge University Press.

Ruble, Blair. 1981. Soviet Trade Unions and Their Development in the 1970s.

Cambridge: Cambridge University Press.

Scott, Jack. 1978. Yankee Unions Go Home: How the AFL Helped the US Build an Empire in Latin America. Vancouver: New Star Books.

Shaiken, Harley and Stephen Herzenberg. 1987. Automation and Global Production: Automobile Production in Mexico, Canada, and the United States. La Jolla: Center for US-Mexican Studies.

Slaughter, Jane. 1987. "Which Side Are They On? The AFL-CIO Tames Guatemala's Unions," The Progressive 51.

Spalding, Hobart. 1988a. "Unions Look South," NACLA: Report on the Americas (MayJune): 14-19.

. 1988b. "AIFLD Amok," NACLA: Report on the Americas (May-June): 20-27.

. 1992. "The Two Latin American Foreign Policies of the US Labor Movement," Science and Society 56(4): 421-439.

Teichman, Judith. 1988. Policymaking in Mexico: From Boom to Crisis. Boston: Allen and Unwin. 
. 1992. "The Mexican State and the Political Implications of Economic Restructuring," Latin American Perspectives 19(1): 88-104.

. 1996. "Economic Restructuring, State-Labor Relations, and the Transformation of Mexican Corporatism," in Neoliberailsm Revisited: Economic Restructuring and Mexico's Political Future, edited by Geraldo Otero. Boulder: Westview Press.

[Page 47]

Journal of World-Systems Research

Trinational Observers Committee (COT). 1997. Reporte de Observacion del Processo. Mexico City.

Waterman, Peter. 1991. Understanding Socialist and Proletarian Internationalism. Working Paper No. 97. Hague: Institute of Social Studies.

Weintraub, Al and William Bollinger. 1987. The AFL-CIO in Latin America: A Look at AIFLD. Oakland: Labor Network.

Windmuller, John. 1954. American Labor and the International Labor Movement, 19401953. Ithaca: Cornell University Press.

[Page 48]

Journal of World-Systems Research

Wood, Ellen Meiskins. 1997. "Globalization and Epochal Shifts: An Exchange," Monthly Review 48(9): 21-32.

Womack, James, Daniel T. Jones, and Daniel Ross. 1990. The Machine That Changed the World: The Story of Lean Production. New York: Harper Collins.

Interviews

Alfaro, Juan Francisco. 1997. Secretary-General, CUSG. Guatemala City. February 5. Arteaga, Arnulfo. 1997. Professor, UAM-Iztapalapa. Mexico City. February 20.

Beckman, Steve. 1997. UAW International Economist. Phone Interview. July 17.

Casertano, Teresa. 1996. FITTIV Representative. Guatemala City. September 25. 
. 1997. FITTIV Representative. Guatemala City. January 18.

Coj, Julio. 1997. International Relations Coordinator, UNSITRAGUA. Guatemala City. February 5.

De la Cueva, Hector. 1997. Director, CILAS. Mexico City. February 20.

Doumitt, Rhett. 1996. US/GLEP Representative. Guatemala City. September 24.

Dueñas, Rigoberto. 1997. Assistant Secretary-General, CGTG. Guatemala City. January 30.

Escobar, Raul. 1997. CILAS/FWDM Representative. Mexico City. February 21.

Fieldman, Bruce. 1996. UNITE Representative. Phone Interview. March.

Gonzalez, Rodridgo. 1997. CEREAL Representative. Mexico City. February 23.

Gonzalez, Zoila. 1997. Second Deputy Minister of Labor. Guatemala City. February 5.

Hermanson, Jeff, 1997. Director of Organizing, UNITE. Phone Interview. October.

Johnson, David. 1994. UE International Representative. Compton, California.

March 31.

Lujan, Bertha. 1996. Secretary-General, FAT, Mexico City. October 2.

MJ Modas Representative. 1997. Guatemala City. February 4.

Markell, Brad. 1996. UAW Region 1A International Labor Solidarity Network. Tijuana, Baja California. October 11.

[Page 49]

Journal of World-Systems Research

Martinez, Benedicto. 1997. Secretary-General, STIMACHS. Mexico City. February 14.

Muñoz, Victor. 1994. AFL-CIO Representative. Tijuana, Baja California. March 10.

[Page 50]

Journal of World-Systems Research 
Parker, David. 1997. Economist, US Department of Labor. Phone Interview.

April 2.

Robles, Rodolfo. 1997. FESTRAS, Secretary-General. Guatemala City. February 7.

Salguero, Flor de Maria. 1997. Mujeres en Solidaridad. Guatemala City. February.

STECAMOSA Union Representatives. 1996. Guatemala City. September 26.

Vasquez, Martin Valenzuela. 1997. Secretary of Internal Organization, National CTM

Ford Workers Union. Cuautitlan, Mexico. February 27.

Newsletters and Periodicals

Campaign for Labor Rights Update

Cerigua

Labor Notes

Maquila Network Update

Mexican Labor News and Analysis

Report on Guatemala

US/GLEP Update

Working Together

$\underline{\text { Endnotes }}$

1 An exhaustive discussion of the history of international labor movements is beyond the scope of this paper. This section merely describes some of the antecedents of contemporary forms of cross-border labor organizing.

2 These periodizations stem from the fact that the First International was founded in 1872 .

$\underline{3}$ The theoretical literature on cross-border labor organizing and labor internationalism is not very well-developed. This section is based on my interpretation of the existing literature and draws on in-depth interviews with academics, labor activists, and union officials in Guatemala, Mexico, and the United States. Interestingly, the academics 
(mostly social scientists) were much more pessimistic about the prospects of cross-border labor organizing than the activists were. For a more thorough theoretical discussion of cross-border labor organizing see, Ralph Armbruster, Globalization and Cross-Border Labor Organizing in the Garment and Automobile Industries (1998, Ph.D. Dissertation).

4 Some scholars, like Emmanuel (1970); Haworth and Ramsey (1988), and Olle and Scholler (1987), claim another factor, wage differences between workers in developed and developing nations, also limits cross-border labor organizing. In fact, Haworth and Ramsey (1988) argue "capital" views "labor" as an abstract factor of production and can move quickly from various locations without any concern for the labor force. However, workers and labor unions are "locally constrained" and spatially fixed. This pessimistic and deterministic model assumes cross-border labor organizing is virtually impossible.

$\underline{5}$ For instance, Disney recently moved some of its production from Haiti to China after the National Labor Committee and several other human rights organizations challenged the company to improve wages and working conditions in its contracting shops.

6 For more information on these organizations see Dunkerly (1988); Jonas (1991); and Payeras (1983). In 1982, EGP, OPRA, the Rebel Armed Forces (FAR), and the Guatemalan Labor Party (PGT) formed a united front, called the Guatemalan National Revolutionary Unity (URNG).

7 There are very few reliable statistics on the maquiladora industry. Most reports indicate that there are about 250-480 maquilas, employing 50,000-120,000 workers (AVANSCO 1994; Grafico 1996; Petersen 1992). The number of small maquila factories in rural areas, along with company officials who do not register with the Guatemalan Labor Ministry, create difficulties in collecting accurate information (Z. Gonzalez 1997).

$\underline{8}$ For security purposes some union activists requested anonymity. Thus, the union affiliation of these activists is used for identification purposes.

9 These three unions are located at the following factories: MJ Modas, Ming-Wa, and Confecciones Unidas (Coj 1997). Some members of the oldest maquila labor union, INEXPORT, are still struggling for their severance payments, but the company recently closed down, and the union exists on paper only (Galacia 1997)

10 These two factories were merged into one in January 1997 (Casertano 1997).

11 However, Guatemala's GSP review was lifted over the objections of Guatemalan labor unions and US/GLEP on May 2, 1997 (US/GLEP Update \#19).

12 These UAW members have requested anonymity. It should be reiterated that not all of these members are affiliated with New Directions. For more information on New Directions, see Moody (1988). 
13 The author thanks one of the anonymous reviewers for emphasizing this point. In my dissertation, I contend that in some cases, structural barriers, like capital mobility, state repression, corporatist state-labor relations, and trade union imperialism, have limitations that provide labor unions with opportunities for cross-border labor organizing (Armbruster 1998). However, these opportunities depend on agency, or in this case, a union's "strategic orientation" or "model of unionism." For further information on these issues see Armbruster (1998) and Dreiling (1997).

[Page 51]

Journal of World-Systems Research 